\title{
Effect of Diet Supplementation with Moringa Oleifera Leaf Meal on Growth and Laying Performances of Female Quail (Coturnix sp.) in Soudano-Guinean Zone of Cameroon
}

\author{
François D. Kouatcho ${ }^{1 *}$, Eliza Simiz ${ }^{2}$, Răzvan M. Radu-Rusu ${ }^{3}$, Golomta Pidotcho ${ }^{1}$, \\ Moussa Djanabou', Ferdinand Ngoula ${ }^{4}$ \\ ${ }^{1}$ University of Ngaoundéré, Department of Biological Sciences, Faculty of Sciences, Po Box 454 \\ Ngaoundéré, Cameroon \\ ${ }^{2}$ Banat's University of Agricultural Sciences and Veterinary Medicine "King Michael I of Romania" from \\ Timisoara, Bioengineering Faculty of Animal Resources, Aradului Street no. 119, 300645, \\ Timisoara, Romania \\ ${ }^{3}$ University of Agricultural Sciences and Veterinary Medicine laşi, Faculty of Animal Science, 3 Mihail \\ Sadoveanu Alley, 700490 laşi, Romania \\ ${ }^{4}$ University of Dschang, Faculty of Agronomy and Agricultural Sciences, \\ Department of Animal Sciences, Cameroon
}

\begin{abstract}
In order to evaluate the effect of diet supplementation with Moringa oleifera leaf meal (MOLM) on growth and laying performances of quail in soudano-guinean zone of Cameroon, a study has been conducted in Ngaoundéré from May to September 2018. For this purpose, a total of 168 seven weeks old quails were divided into 12 comparable batches of 10 females and 4 males. Each of the four experimental diets (T0, T1, T2 and T3), formulated on the basis of the level $(0,1,2$, and $3 \%$ respectively) of diet supplementation with MOLM was randomly assigned to 03 batches in a completely randomized. Data were collected during the 16 weeks of the study on feed intake (FI), body weight (BW), body weight gain and feed conversion ratio. Weekly, after total laid eggs evaluation, 40 eggs per treatment was randomly chosen, weighed and measured. Main findings revealed that FI was not significantly affected by the diet supplementation with MOLM. Significantly higher BW and BW gain was recorded in T1 treatment compared to others treatments while they remains similar between them. The relatively heavier eggs were noted in T2 treatment while the highest $(88.57 \pm 2.85 \%)$ weekly laying rate was recorded with $1 \%$ supplementation. It has then been concluded that MOLM could be used as diet supplement during laying phase up to $3 \%$ for egg production and $1 \%$ of substitution seem to be the most appropriate to increase eggs laying rate while $2 \%$ is suitable to obtain heavy eggs in the soudano-guinean agro ecological zone of Cameroon.
\end{abstract}

Keywords: Supplementation, Moringa oleifera, growth, laying, quail.

\section{Introduction}

Quail farming is an alternative source of protein supply, given the limitations of modern poultry farming and the need to diversify the origins of

\footnotetext{
* Corresponding author: François D. Kouatcho, franckdjitie@gmail.com

(cc)) EY-NC-ND $\odot$ 2020 F. D. Kouatcho et al., published by De Gruyter Open. This work was licensed under the Creative Commons Attribution-NonCommercialNoDerivs 3.0 License
}

animal proteins. Quail generates great interest in Cameroon because of its many assets, notably its resistance to diseases, the low production cost associated to its small size, rapid growth and relatively short life cycle $[1,2]$. It also has a high egg production $[3,4]$ and according to Tunsaringkam et al. [5], their eggs are apparently therapeutic. In Cameroon, this species has been the subject of some study. Djitie et al. [6] studied the growth aspect by studying the effect of crude 
protein in quails in the finishing phase. Their work showed that the protein level of diets does not significantly affect feed intake. Djitie et al. [7] were interested in the prediction of sexual maturity in male quail based on hormonal profiles, testicular and semen characteristics. Their work led them to the conclusion that the age at maturity in male quail can be around 12 weeks in the agro-climatic conditions of the western highlands of Cameroon. However, the reproductive aspect in the female remains unexplored in the context of Cameroon. Moringa oleifera is a plant cultivated in Cameroon whose leaves are rich in proteins, vitamins (A, B and $E$ ), minerals (calcium, potassium, and magnesium) $[8,9,10]$ and essential amino acids for humans and animals.

Numerous studies have shown the beneficial effects of using leaves of this plant in animal feed in general and in poultry particularly. Works of Teteh et al. [11] on hens showed that the incorporation of $1 \%$ of $M$. oleifera leaves meal during the laying period increased the number of eggs as well as their weight. Since the nutritional needs of quails are not well controlled in Cameroon environment [7, 12, 13], feed supplementation with $M$. oleifera leaf meal could compensate nutritional deficiencies and thus contribute to improve the reproductive performance of quails. In this context that the present study, whose general objective is to contribute to the improvement of quail growth and laying performances in the Sudano-Guinean zone of Cameroon, has been conducted.

Specifically, the aim was to determine the effect of the incorporation rate of $M$. oleifera leaf powder on growth parameters, laying performance and egg characteristics.

\section{Material and Methods}

Presentation of the study area

The study was conducted in Ngaoundéré in the Sudano Guinean zone of Cameroon. The area is located between the 6th and 8th degrees North Latitude and between the 10th and 16th degree East Longitude with an average altitude of 1000 $\mathrm{m}$. There is one rainy season of 8 months (April to November) and a dry season of 4 months (December to March). The rainfall is between 1500 and $1800 \mathrm{~mm} / \mathrm{year}$, the average annual humidity varies between $64.1 \%$ and $67.6 \%$ and the temperatures between 23 and $32^{\circ} \mathrm{C}$. Soils are generally fertile and appropriate for agro-pastoral activities. Vegetation consists mainly of shrub or tree savannahs. Livestock is mainly cattle and small ruminants. Poultry farming is still very little developed [14].

Materials and essay follow-up

$M$. oleifera leaves were cut early in the morning and then dried in the shade before being transformed into powder and kept until use.

A total of 168 quails of 7 weeks old were divided into 12 similar batches of 14 birds (10 females and 4 males). They were housed in cages made of low-meshed planks and wire mesh at a density of $28 \mathrm{birds} / \mathrm{m}^{2}$. Four experimental diets (T0, T1, T2 and T3) formulated on the basis of the level ( 0 , 1,2 and $3 \%$ ) of supplementation of the basic diet with $M$. oleifera leaves meal in the reproductive phase. The percentage composition and the calculated chemical characteristics of the basic ration are recorded in Table 1.

\section{Feed percentage composition and calculated chemical characteristics}

Table 1.

\begin{tabular}{|c|c|}
\hline Ingredients & Quantity (Kg) \\
\hline Maize & 63 \\
\hline Wheat bran & 4 \\
\hline Soybean meal & 14 \\
\hline Fishmeal & 5 \\
\hline Shellfish flour & 1 \\
\hline Bone meal & 1 \\
\hline CMAV 5\% laying & 5 \\
\hline Palm oil & 2 \\
\hline Groundnut meal & 5 \\
\hline Total & 100 \\
\hline
\end{tabular}


Experimental diets were formulated by adding 0 , 1,2 and $3 \%$ of the feed weight by $M$. oleifera leaves meal corresponding to treatments T0, T1, T2 and T3 respectively.

Each of the 4 experimental diets was randomly assigned to 3 batches in a completely randomized design corresponding to 4 treatments repeated 3 times each. Water and feed were distributed ad libitum throughout the 16 weeks of the trial. Except the experimental diet, all birds benefited from similar management conditions.

\section{Data collection \\ Growth performance}

Experimental diets were weighed at the beginning of the week and distributed daily. Leftovers of each experimental unit were weighed every 7 days using an electronic scale of $5000 \mathrm{~g}$ range and $1 \mathrm{~g}$ accuracy. Weekly feed intake (FI) was calculated as the difference between the amount of feed distributed during the week and leftovers of the same week.

At the beginning of the test and every 7 days after, quails were weighed on an empty stomach in the morning using an electronic scale of $2000 \mathrm{~g}$ range and $0.1 \mathrm{~g}$ accuracy. The weekly weight gain was obtained by making the difference between two consecutive live weights.

Feed consumption of each week was divided by weekly average weight gain for the same period to obtain the Feed Conversion Ratio (FCR).

Laying rate

During the laying period, eggs were collected and count daily in each batch. For each experimental unit, total eggs laid were calculated by simple addition of eggs laid during 7 days. Laying rate was calculated as follows:

Laying rate $=100 x \frac{\text { Number of eggs laid in per week }}{\text { Number of female } \mathrm{x} 7}$
Egg weight and measurements

The egg weight was measured with an electronic balance to the nearest $0.01 \mathrm{~g}$.

The egg high and width were measured with a digital caliper of $150 \mathrm{~mm}$ range and $0.01 \mathrm{~mm}$ accuracy. The egg shape index (\%) was calculated as follow (diameter/height) $\times 100$.

\section{Statistical analysis}

The data obtained were expressed as mean \pm standard deviation on the mean. One-way analysis of variance (ANOVA) was used according to the general linear model to compare the means of the different parameters. Duncan test was used at the $5 \%$ significance level to separate means in case of differences between treatments. IBM SPSS Statistics 21.0 software was used for analyzes.

\section{Results}

Effect of supplementation of $M$. oleifera leaf powder feed on quail growth.

The effects of the level of diet supplementation with $M$. oleifera leaf meal on average quail production performances at 23 weeks are recorded in Table 2. It appears from this table that the level of supplementation of $M$. oleifera leaf meal did not significantly affect the feed intake (FI) of quails. However, there was a decrease in FI with the rate of supplementation, although values were similar $(P>0.05)$. The relatively highest $\mathrm{FI}$ $(246.44 \pm 17.83 \mathrm{~g})$ was recorded with the control while the lowest $(228.89 \pm 11.25 \mathrm{~g})$ was recorded with T3 treatment. Body weight (BW) and body weight gain were significantly affected by the level of feed supplementation. Treatment T2 induced highest body weight and weight gain as compared to the other treatments, which remained comparable. In general, MOLM has increased body weight and body weight gain as compared to the control.

Table 2.

Average production performances as affected by the exponential diets at 23 weeks of age

\begin{tabular}{cccc}
\hline Treatments & \multicolumn{3}{c}{ Average production performances } \\
\cline { 2 - 4 } & Feed Intake $\mathbf{( g )}$ & Body weight $(\mathbf{g})$ & Body weight gain $\mathbf{( g )}$ \\
\hline T0 & $246.44 \pm 17.83^{\mathrm{a}}$ & $271.17 \pm 10.19^{\mathrm{a}}$ & $18.62 \pm 2.58^{\mathrm{a}}$ \\
T1 & $235.26 \pm 19.97^{\mathrm{a}}$ & $287.02 \pm 10.70^{\mathrm{b}}$ & $34.09 \pm 5.46^{\mathrm{b}}$ \\
T2 & $229.50 \pm 15.45^{\mathrm{a}}$ & $272.20 \pm 7.28^{\mathrm{a}}$ & $19.33 \pm 3.15^{\mathrm{a}}$ \\
T3 & $228.89 \pm 11.25^{\mathrm{a}}$ & $273.29 \pm 9.84^{\mathrm{a}}$ & $20.84 \pm 3.39^{\mathrm{a}}$ \\
\hline Average & $235.02 \pm 16.12$ & $275.92 \pm 9.50$ & $23.22 \pm 3.64$ \\
\hline
\end{tabular}

$a, b:$ in the same column, values assigned with the same letter are not significantly different $(P>0.05)$ 


\section{Feed intake}

The weekly feed intake of quails as a function of the level of feed supplementation with $M$. oleifera leaf meal (Figure 1) has been irregular. It has generally increased for all treatments. However, the control treatment induced relatively higher values over the entire trial period. Nevertheless, at some weeks $(13,19$, and 21), the control batch FI was significantly higher than those of other treatments. At the end of the trial (week 23), although the values were comparable $(P>0.05)$, the relatively highest value $(255.14 \pm 11.00 \mathrm{~g})$ was recorded with the control treatment while the lowest $(225.92 \pm 0.64 \mathrm{~g})$ was recorded with $1 \%$ supplementation of the feed with $M$. oleifera leaf meal.

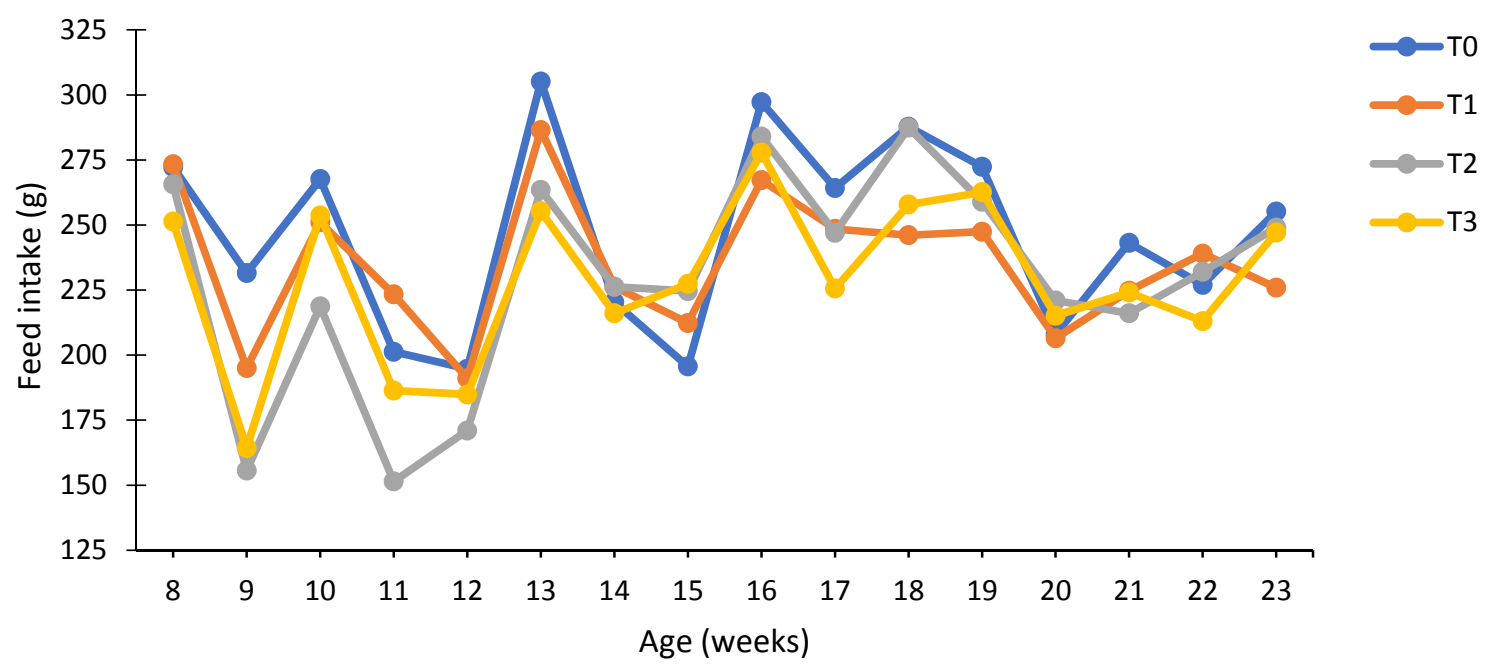

Figure 1. Weekly feed intake evolution as affected by experimental diets

\section{Body weight}

Figure 2 shows the evolution of quail live body weight with the rate of supplementation of feed with $M$. oleifera leaf meal. For the most part, the supplementation resulted in a higher live weight than the control batch. Except at the 9th week of age where the body weight of treatment supplemented at $1 \%$ with MOLM was lower than those of treatments T2 (2\%) and T3 (3\% of
MOLM). Globally, supplemented diets induced significantly higher body weights than the other treatments over the whole period of the study. At the end of the trial, significantly higher body weights $(287.02 \pm 10.70 \mathrm{~g})$ were recorded in females consuming feed supplemented with $1 \%$ M. oleifera leaf meal compared to T0, T2 and T3 which were comparable with each other.

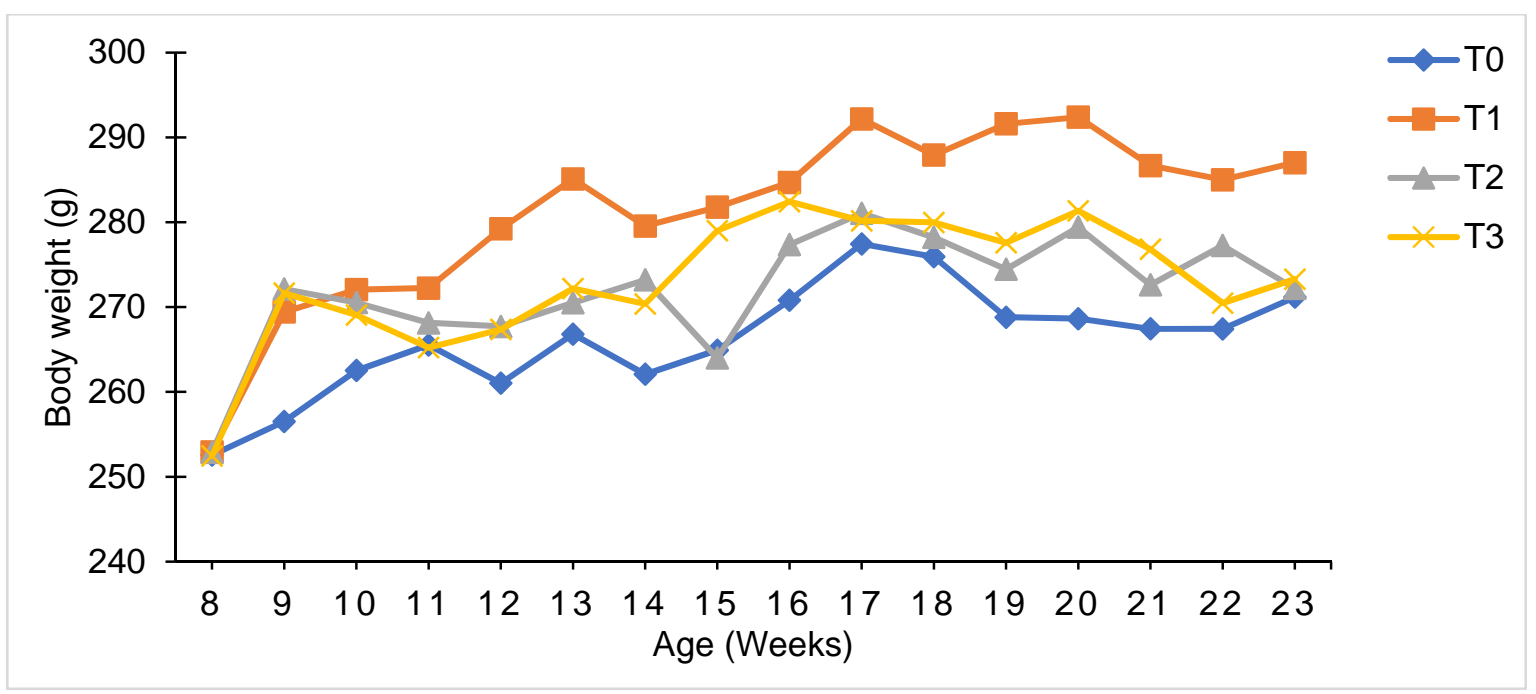

Figure 2. Weekly body weight evolution as affected by experimental diets 


\section{Feed conversion ratio}

Figure 3 shows the evolution of the feed conversion ratio (FCR) of quails in relation to the level of feed supplementation with $M$. oleifera leaf meal. Except at week 9, where FCR considerably dropped for all treatments, FCR increased globally. Treatment TO induced relatively higher FCR values over the entire trial period with some cases where the differences were significant (weeks 9, 19 and 20). At the end of the study, the FCR of treatments T0 $(3.82 \pm 0.31)$ and T2 $(3.94 \pm 0.25)$ were significantly higher $(P<0.05)$ than those of treatment $\mathrm{T} 1 \quad(3.12 \pm 0.09)$ but equivalent $\quad(P>0.05) \quad F C R$ of treatment T3

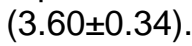

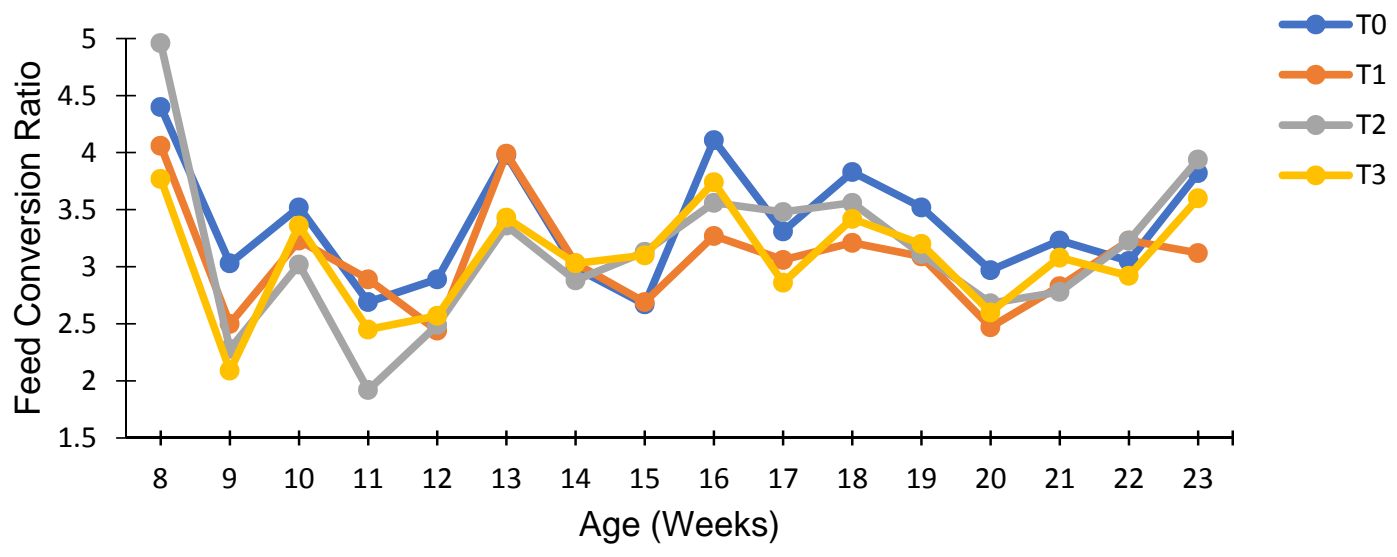

Figure 3. Weekly feed conversion ratio variation as affected by experimental diets

Effect of diet supplementation with M. oleifera leaf meal on egg-laying performances and eggs characteristics.

Table 3 presents the effects of the rate of diet supplementation with $M$. oleifera leaf meal on the average egg laying performances and eggs characteristics of quails at 23 weeks of age. It appears that the level of diet supplementation with MOLM significantly influenced the quail egg-laying rate $(P<0.05)$. The egg-laying rate of treatment T1 $(88.57 \pm 2.85 \%)$ was significantly higher than the one of $2 \%$ supplementation but similar to the control and T3 while the egg-laying rate of treatment T2, T0 and T3 were also comparable between them. The relatively lower egg weight was recorded with T1 who also presented the relatively bigger weekly mass egg production despite the fact that despite the fact that all egg characteristics were not significantly affected by the level of supplementation of feed with $M$. oleifera leaf meal.

The relatively lower egg weight was recorded with T1 who also presented the relatively bigger weekly egg mass production.

Table 3.

Laying performances and eggs characteristics as affected by the level of supplementation of diet with MOLM in quail at 23 weeks age

\begin{tabular}{ccccccc}
\hline $\begin{array}{c}\text { Experimental } \\
\text { diets }\end{array}$ & $\begin{array}{c}\text { Laying rate } \\
(\mathbf{\%})\end{array}$ & $\begin{array}{c}\text { Eggs } \\
\text { weigth } \\
\mathbf{( g )}\end{array}$ & $\begin{array}{c}\text { Heigh } \\
\mathbf{( m m )}\end{array}$ & widh (mm) & $\begin{array}{c}\text { Shape } \\
\text { index (\%) }\end{array}$ & $\begin{array}{c}\text { Weekly eggs } \\
\text { mass } \\
\text { production (g) }\end{array}$ \\
\hline T0 & $81.90 \pm 10.03^{\mathrm{ab}}$ & $11.72 \pm 0.58^{\mathrm{a}}$ & $33.18 \pm 1.14^{\mathrm{a}}$ & $25.34 \pm 0.47^{\mathrm{a}}$ & $76.45 \pm 3.04^{\mathrm{a}}$ & $67.19 \pm 8.23^{\mathrm{a}}$ \\
T1 & $88.57 \pm 2.85^{\mathrm{b}}$ & $11.65 \pm 0.62^{\mathrm{a}}$ & $33.20 \pm 0.80^{\mathrm{a}}$ & $25.31 \pm 0.58^{\mathrm{a}}$ & $76.28 \pm 2.00^{\mathrm{a}}$ & $72.23 \pm 2.33^{\mathrm{a}}$ \\
T2 & $73.33 \pm 4.36^{\mathrm{a}}$ & $12.26 \pm 0.74^{\mathrm{a}}$ & $33.76 \pm 0.90^{\mathrm{a}}$ & $25.75 \pm 0.73^{\mathrm{a}}$ & $76.30 \pm 2.38^{\mathrm{a}}$ & $62.93 \pm 3.74^{\mathrm{a}}$ \\
T3 & $82.85 \pm 2.85^{\mathrm{ab}}$ & $11.85 \pm 1.05^{\mathrm{a}}$ & $32.80 \pm 1.45^{\mathrm{a}}$ & $25.69 \pm 0.88^{\mathrm{a}}$ & $78.43 \pm 3.62^{\mathrm{a}}$ & $68.73 \pm 2.37^{\mathrm{a}}$ \\
\hline Average & $81.66 \pm 5.02$ & $11.87 \pm 0.74$ & $33.23 \pm 1.07$ & $25.52 \pm 0.66$ & $76.87 \pm 2.87$ & $67.77 \pm 4.16$ \\
\hline
\end{tabular}

$a, b$ : in the same column, values assigned with the same letter are not significantly different $(P>0.05)$

Laying rate

Analysis of the quail laying curve as a function of the level of feed supplementation with M. oleifera leaf meal (Figure 4) shows that it has evolved irregularly. It increased up to 19 weeks of age and then dropped at the end of the trial. Taken as a 
whole, birds feeding with diet containing $1 \% \mathrm{M}$. oleifera leaf meal had a relatively high laying rate compared to the other treatments, with periods where the differences were significant $(8,9,10$, 16 and 23 weeks of age).

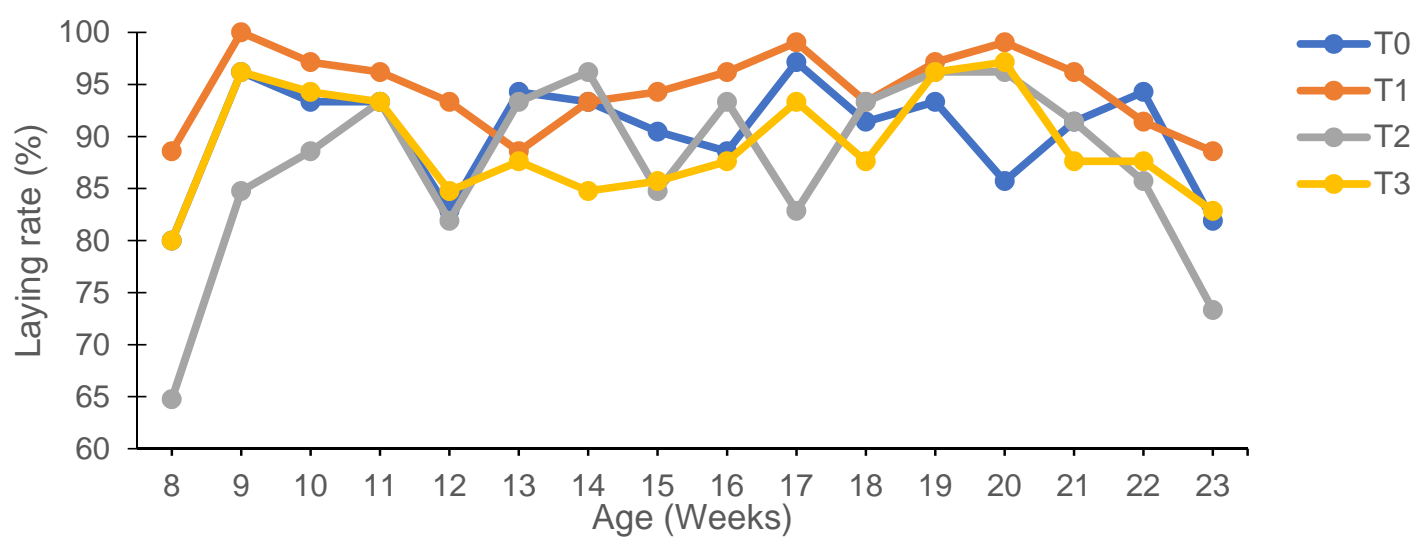

Figure 4. Laying rate evolution as affected by the experimental diets

\section{Discussions}

The results of our study showed that the feed intake of quails was not significantly affected by the level of feed supplementation with $M$. oleifera leaf meal. However, it decreased with the level of supplementation of feed with $M$. oleifera leaf meal. This decrease in FI may be explained by an increase in anti-nutritional factors with the level of supplementation. These observations confirm the results of Banjo [15] who studied the effect of four levels of inclusion of $M$. oleifera leaf meal $(0 \%$, $1 \%, 2 \%$ and $3 \%$ ) on growth performance of broilers. According to this author, the level of supplementation did not significantly affect feed intake and feed conversion ratio but significantly increased the weight gain of birds at $2 \%$. Our observations also corroborate with those of AbouElezz et al. [16] in Cuba who obtained comparable feed intake in laying hens with four levels of supplementation $(0,5,10$, and $15 \%)$ of $M$. oleifera leaf meal.

Diets supplemented with $M$. oleifera leaf meal induced higher live weight and mean weight gain than those of the control treatment. However, 1\% substitution of feed with $\mathrm{M}$. oleifera leaf meal induced significantly higher body weight and weight gain than treatments with $2 \%$ and $3 \%$ of $M$. oleifera leaf meal. This increase in birds' body weight can be explained by an increase in nutrient uptake leading to an increase in body weight. The reduction in body weight and average weight gain recorded with $2 \%$ and $3 \%$ treatments can be explained by an increase in the concentration of fiber in the feed, which may compromise digestibility in quail which is a monogastric animal and therefore cannot easily or efficiently assimilate diet fibers [1]. These results were corroborated with the observations of Chongwe [17] who studied the effect of $M$. oleifera leaf meal supplementation $(0 \%, 10 \%, 20 \%$ and $30 \%)$ on the growth and health of native chickens. However, our observations are in contrast to those of Banjo [15] who instead noted a significant increase in weight gain in broilers with $2 \%$ supplementation of the feed with $M$. oleifera leaf meal feed. Our results show that feed conversion ratio was not significantly affected by the level of feed supplementation with $M$. oleifera leaf meal.

The level of supplementation significantly affected the quail egg-laying rate. Birds consuming $1 \%$ diet supplemented with $M$. oleifera leaf meal had a significantly higher laying rate compared to the other treatments. M. oleifera leaf meal is rich in vitamin E, zinc and magnesium, which according to NRC [18] contribute to improve egg production. The decrease in the egg-laying rate in 2 and 3\% treatments can be explained by high levels of these elements which, at high rates would have driven to the opposite effect. These observations corroborate with the results of Teteh et al. [19] who studied the effect of $M$. oleifera leaf meal on egg laying rate, egg quality and blood parameters of hens by exposing them to three experimental diets containing different amounts of $M$. oleifera $(0,1$ and $2 \%)$. Their results showed that diets supplemented with $1 \%$ induced high egg production and the heaviest eggs compared to the others. However, our observations contrast with 
those of Swain et al. [20] in India, who studied the effect of five levels of supplementation $(0 ; 0.5 ; 1$; 1.5 and $2 \%$ ) of feed with $M$. oleifera leaf meal in hens. They noticed a significant increase in the laying rate and feed conversion ratio at $0.5 \%$ supplementation.

Supplementation of feed with $M$. oleifera leaf meal did not significantly impact eggs weight, height, diameter, egg shape index and weekly egg mass of quails. However, the relatively heavier eggs and those with a high height were recorded in quails consuming the feed supplemented at $2 \%$ with $M$. oleifera leaf meal. According to Sauveur [3], lowering the protein level in the diet leads to a reduction in egg weight. Since $M$. oleifera leaf meal is high in protein, the increase in egg weight with 2 and $3 \mathrm{M}$ treatments can be explained by the high protein content in these diets compared to diets supplemented with 0 and $1 \%$ with $M$. oleifera leaf meal. Our findings are in agreement with those of Wei Lu et al. [21] in China who studied the effect of four levels of supplementation $(0,5$, 10 and $15 \%$ ) of $M$. oleifera leaf meal on egg laying performance, egg quality, plasma biochemistry and organ histopathological indices in hens. These authors reported that there was no significant difference between the different treatments with regard to egg weight.

\section{Conclusions}

At the end of our work on the effect of feed supplementation with $M$. oleifera leaf meal feed on the growth and laying performance of quail in the Sudano-Guinean area of Cameroon, the main conclusions shows that feed supplementation with $1 \% M$. oleifera leaf powder results in the best growth performance in quails in the breeding phase in terms of live weight and average weight gain. Diet supplemented with $1 \% M$. oleifera leaf meal also results in a better egg-laying rate, while the $2 \%$ and $3 \%$ supplementation levels improve egg weight.

Moringa oleifera leaf meal could be therefore suitable for quails during reproduction period and $1 \%$ supplementation of the feed seem to be the most appropriate in the context of the study area.

\section{References}

1. INRA. (1989). L'alimentation des animaux monogastriques. Porcs, lapins, volailles. 2ème Ed. INRA, Paris, 282p.

2. Kayang, B.B., Vignal, A., Inoue-Murayama, M., Mmiva, Lmonvoisin J., Sito \& Minvielle, F. (2004). A first génération microsatellite linkage map of the Japanese quail. Animal Génétics, 35, 195-200. http://doi.org/10.1111/i.1365-2052.2004.01135.x

3. Sauveur, B. (1988). Reproduction des volailles et production d'œufs. INRA Editions, Paris, France, 450p.
4. Biagini, F. (2006). Petits et mini-élevages dans le monde: principales espèces d'intérêt. Synthèse bibliographique. Biologie géosciences agro ressources et environnement productions animales en régions chaudes synthèse. Ecole Nationale Supérieure Agronomique de Montpellier Place Viala, 34060 Montpellier Cedex Master. 31 p.

5. Tunsaringkarn, T., Tungjaroenchai, W., \& Siriwong, W. (2013). Nutrient Benefits of Quail (Coturnix coturnix japonica) Eggs. International Journal of Scientific and Research Publications, 3(5), 1-8.

6. Djitie, K.F., Kana J.R., Ngoula F., Nana N.F.C., \& Teguia A. (2015a). Effect of dietary crude protein level on growth parameters and carcass characteristics of quail (Coturnix sp.) at finisher stage in Western Highlands of Cameroon. Livestock Research for Rural Development, 27, 155. Retrieved August 6, 2018, from http://www.Irrd.org/lrrd27/8/koua27155.htm

7. Djitie, K.F., Kenfack, A., Ngoula, F. \& Teguia A. (2015b). Sexual maturity prediction based on hormonal profiles, testes and semen characteristics in male Coturnix quail (Garsault, 1764) in Western Highlands of Cameroon. International Journal of Agronomy and Agricultural Research, 7, 4, 143-154. http://www.innspub.net

8. Moyo, B., Patrick J.M., Arnold H. \& Voster M. (2011). Nutritional characterization of moringa (Moringa oleifera Lam.) leaves. African Journal of Biotechnoloy, 10, 12925-12933. http://doi.org/10.5897/AJB10.1599

9. Ndong, M., Wade, Salimata, Dossou, N., Guiro, Amadou, T., Gning \& Rokhaya D. (2007). Valeur nutritionnelle du Moringa oleifera, étude de la biodisponibilité du fer, effet de l'enrichissement de divers plats traditionnels sénégalais avec la poudre des feuilles. African Journal of Food, Agriculture, Nutrition and Development, $7(3 \& 4)$.

10. Broin, M. (2005). Composition nutritionnelle des feuilles de Moringa oleifera. CTA. 5.

11. Teteh A., Gbeassor M., Decuypere E. and Tona K. (2016). Effects of Moringa oleifera Leaf on Laying Rate, Egg Quality and blood Parameters. International Journal of Poultry Science, 15 (7): 277-282. http://scialert.net/abstract/?doi=ijps.2016.277.282

12. Djitie K.F., Moussa D., Mamadou, K, Friki L.N., Aoudou, B., Golomta, P., Teguia, A. (2019). Effect of feed supplementation by Moringa oleifera leaves meal on quail (Coturnix sp.) production performances in the sudano-guinean zone of Cameroon. Scientific Works. Series C. Veterinary Medicine, LXV, 2, 61-68.

13. Katchouang, A.S.N., Djitie, F.K., Meutchieye, F., Kana, J.R., \& Teguia A. (2015). Caractéristiques des élevages de caille (Coturnix sp.) dans le département du Mfoundi, région du Centre, Cameroun. Livestock Research for Rural Development, 27, 77. Retrieved December 1, 2018, from http://www.Irrd.org//rrd27/4/katc27077.html

14. Tchuenguem, F.F.N., Djonwangwe D., Messi J. \& Brückner D. (2009). Activité de butinage et de pollinisation de Apis mellifera adansonii Latreille (Hymenoptera: Apidae) sur les fleurs de Helianthus annuus (Asteraceae) à Ngaoundéré (Cameroun). Cameroon Journal of Experimental Biology, 05 N 01, 19. http://doi.org/10.4314/cajeb.v5i1.44442 
15. Banjo, O.S. (2012). Growth and Performance as affected by inclusion of Moringa oleifera leaf meal in Broiler chicks diet. Journal of Biology, Agriculture and Healthcare, ISSN 2224-3208 (Paper) ISSN 2225-093X (Online) 2, 9.

16. Abou-Elezz, F.M.K., Sarmiento-Franco. L., Santos-Ricalde. R., \& Solorio-Sánchez F. (2011). Nutritional effects of dietary inclusion of Leucaena leucocephala and Moringa oleifera leaf meal on Rhode Island Red hens' performance. Cuban Journal of Agricultural Science, 45, 163-169.

17. Chongwe, M.A. (2011). The effect of Moringa supplementation on growth and health of indigenous zambian chickens. M.Sc. dissertation, University of Zambia, Lusaka, Zambia. 47pp.

18. NRC, (1994). Nutrient Requirements of Poultry. National Research Council, National Academy Press, Washington, D. C., ninth Revised Edition. Pp. 44.
19. Tesfay, S.Z., Bertling I., Odindo A.O., Seyoum Workneh, T., \& Mathaba, N., (2011). Levels of antioxidants in different parts of moringa (Moringa oleifera) seedling. African Journal of Agricultural Research, 6(22), 5123-5132.

20. Swain, B.K., Naik, P.K., Chakurkar, E.B. \& Singh N.P. (2017). Effect of supplementation of Moringa oleifera leaf meal (MOLM) on the performance of Vanaraja laying hens. Indian Journal of Animal Sciences, 87(3), 353-355.

21. Wei, L., Wang, J., Zhang, H.J., Wu, S.G., \& Qi, G.H. (2016). Evaluation of Moringa oleifera leaf in laying hens: effects on laying performance, egg quality, plasma biochemistry and organ histopathological indices. Italian Journal of Animal Science, 15(4), 658-665, http://doi.org/10.1080/1828051X.2016.1249967 